\title{
Where Have All the Birds Gone?
}

Essays on the Biology and

Conservation of

Birds That Migrate to the American Tropics

BY JOHN TERBORGH

PRINCETON UNIVERSITY PRESS 
Copyright ( $(1989$ by Princeton University Press Published by Princeton University Press, 41 William Street, Princeton, New Jersey 08540

In the United Kingdom: Princeton University Press, Chichester, West Sussex

All Rights Reserved

Library of Congress Cataloging-in-Publication Data

Terborgh, John, 1936-

Where have all the birds gone? : essays on the biology and conservation of birds that migrate to the American tropics / John Terborgh

p. $\mathrm{cm}$.

Bibliography: $p$.

Includes index.

ISBN 0-691-08531-5 (cloth) - ISBN 0-691-02428-6 (pbk.)

1. Birds-Migration. 2. Birds-Tropics. 3. Birds-Ecology.

4. Birds, Protection of. I. Title

QL698.9.T44 1989

598.2'525-dc19 89-3733

This book has been composed in Linotron Times Roman

Princeton University Press books are printed on acid-free paper and meet the guidelines for permanence and durability of the Committee on Production Guidelines for Book Longevity of the Council on Library Resources

Printed in the United States of America by Princeton Academic Press

$\begin{array}{lllll}9 & 8 & 7 & 6 & 5\end{array}$ 
WHERE HAVE ALL THE BIRDS GONE? 

To my long-suffering parents

for their tolerance and understanding 
